\title{
STURNUS LUDOVICIANUS.
}

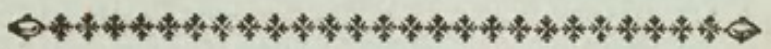

CHARACTER GENERICUS.

Roftrum fubulatum, angulato-depreffum, obtufiufculum : Mandibula fuperiore integerrima, marginibus patentiufculis.

Nares fupra marginatæ.

Lingua emarginata, acuta.

$$
\text { Lin. Syft. Nat. p. } 290 .
$$

CHARACTER SPECIFICUS, $\Xi^{\circ} \mathrm{C}$.

STURNUS grifeo fufcoque maculatus, fubtus flavus, linea capitis fuperciliifque albis, gula nigra.

$$
\text { Lath. ind. orn. p. } 323 \text {. }
$$

STURNUS Ludovicianus.

$$
\text { Lin. Syft. Nat. p. } 290 .
$$

ALAUDA magna.

$$
\text { Lin. Syft. Nat. p. } 28 \mathrm{~g} \text {. }
$$

In variis America Septentrionalis partibus generatur avis quam depinximus, fturno vulgari paulo major. Variat coloribus. Interdum enim evenit ut cingatur 
cingatur utrinque guttur linea nigra, quæ fenfim fe dilatans quafi lunulam nigram ducit trans pectus; quæ lunula in aliis fpeciminibus vix ac ne vix vifibilis eft. Nonnullorum quoque fpeciminum albent remiges externi. In editione duodecima Syftematis Linnæani dantur huic avi duo diverfa genera, Sturni nempe et Alaudæ, ab experientia autem fatis jam compertum eft varietates ejufdem fpeciei caufam fuiffe erroris. 


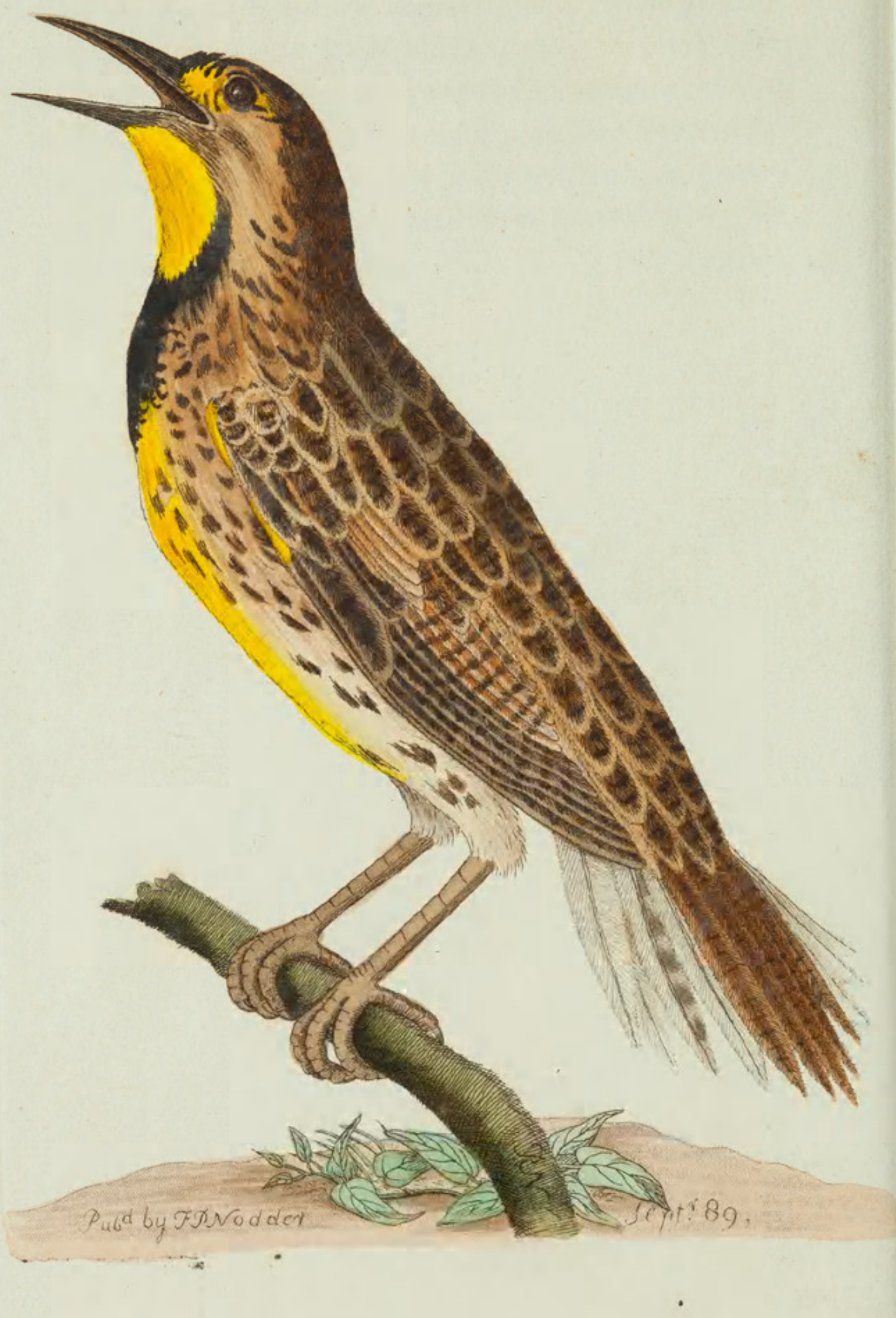


THE

\section{CRESCENT STARLING.}

Q

GENERIC CHARACTER.

Bill ftrait, depreffed.

Noftrils guarded above by a prominent rim.

Tongue hard and cloven.

Middle Toe united to the outmoft as far as the firft joint.

$$
\text { Latb. Synops. 2. p. } 1 .
$$

$$
\text { SPECIFIC CHARACTER, E'C. }
$$

Pale-brown STARLING fpotted with dufky: beneath yellow with black throat.

Large LARK.

Louifiane STARE.

$$
\text { Catefb. Car. 1. p. 33.pl. } 33 \text {. }
$$

$$
\text { Lath. Syn. 2. p. } 6 .
$$

Crefcent STARE.

$$
\text { Penni. Arct. Zool. 2. p. } 330 .
$$

ETOURNEAU de la Louifiane.

$$
\text { Buf. ois. 3. p. 192. Pl. enl. } 25^{6} .
$$

The bird here reprefented is found in feveral parts of North America, and in fize fomewhat exceeds 
the common Starling. It is fubject to fome variety in point of colour; the throat in fome fpecimens being black, which defcends in a dilated band beneath, fo as to form a black crefcent acrofs the breaft; while in others this appearance is fcarce perceptible. The external tail-feathers are alfo white in fome individuals. This bird in the twelfth edition of the Syftema Naturæ was arranged under two different genera; viz. thofe of Sturnus and Alauda ; but later obfervations have proved the varieties, which caufed this impropriety, to belong to the felf fame fpecies. 


\section{$2 \mathrm{BHL}$ Biodiversity Heritage Library}

Shaw, George. 1798. "The Crescent Starling, Sturnus ludovicianus [PI. 349]." The Naturalist's Miscellany 10(CIX), https://doi.org/10.5962/p.304531.

View This Item Online: https://www.biodiversitylibrary.org/item/276641

DOI: https://doi.org/10.5962/p.304531

Permalink: https://www.biodiversitylibrary.org/partpdf/304531

\section{Holding Institution}

Museums Victoria

\section{Sponsored by}

Atlas of Living Australia

\section{Copyright \& Reuse}

Copyright Status: Public domain. The BHL considers that this work is no longer under copyright protection.

This document was created from content at the Biodiversity Heritage Library, the world's largest open access digital library for biodiversity literature and archives. Visit BHL at https://www.biodiversitylibrary.org. 